\title{
PENGARUH SUPLEMENTASI SENG TERHADAP KEJADIAN TONSILITIS PADA BALITA
}

\author{
Gita Zeny Prasetya ${ }^{1}$, Aryu Candra ${ }^{1}$, Dewi M Kurniawati ${ }^{1}$ \\ ${ }^{1}$ Departemen Ilmu Gizi, Fakultas Kedokteran, Universitas Diponegoro \\ Jln. Prof. H. Soedarto, SH., Semarang, Telp (024) 76402881, Email : gizifk@ undip.ac.id
}

\begin{abstract}
Backgroud : Tonsillitis is one of the Upper Respiratory Tract Infections (URTI) that often occurs in toddlers. Zinc plays an important role in human immune system. Zinc supplementation can enhance the immune system, so it can reduce the incidence of URTI including tonsillitis. The aim of this study is to determine the effect of zinc supplementation on the incidence of tonsillitis in toddlers.

Methods : This was a true experimental study with post test only control group design. The subjects in this study were 40 toddlers aged 2-5 years who were randomized into two groups; control group were given placebo syrup, and intervention group were given $10 \mathrm{mg} /$ day of zinc supplement for 2 months. Incidence data of tonsillitis were obtained at the end of the intervention through anamnesis and physical examination. Data were analyzed using Independent T-test and Mann Whitney U-test.

Result: The mean level of zinc adequacy during the study in the control group was 137,42 \pm 50,05 and in the intervention group 352,84 $\pm 48,54$. The mean frequency of tonsillitis incidence in control group was higher compared to the intervention group, which was 0,26 $\pm 0,562$ times, while the intervention group was 0,21 $\pm 0,419$ times. There were no differences in the frequency and the scores of symptoms of tonsillitis between the control and intervention group. $(p>0,05)$ Conclusion: The mean incidence of tonsillitis in the control group was higher than the intervention group. There was no statistically difference in the incidence of tonsillitis between both groups.
\end{abstract}

Keywords : URTIs, tonsillitis, zinc supplementation

\begin{abstract}
ABSTRAK
Latar Belakang : Tonsilitis merupakan salah satu infeksi pada saluran pernapasan bagian atas (ISPA) yang sering terjadi pada balita. Seng berperan pada sistem kekebalan tubuh manusia. Pemberian suplementasi seng dapat meningkatkan sistem kekebalan tubuh dan dapat menurunkan kejadian ISPA termasuk tonsilitis. Tujuan penelitian ini untuk mengetahui pengaruh suplementasi seng terhadap kejadian tonsilitis pada balita.

Metode : Penelitian true eksperimental dengan post test only control group design. Subjek dalam penelitian ini adalah 40 balita berusia 2-5 tahun yang dibagi menjadi 2 kelompok, yaitu kelompok kontrol (mendapat sirup placebo) dan kelompok intervensi (mendapat suplemen seng $10 \mathrm{mg} / \mathrm{hari}$ selama 2 bulan). Data kejadian tonsilitis diperoleh pada akhir intervensi melalui anamnesis dan pemeriksaan fisik. Data dianalisis menggunakan uji Independent T -Test dan Mann Whitney U-Test.

Hasil: Rerata tingkat kecukupan seng pada kelompok kontrol selama penelitian 137,42 \pm 50,05 dan pada kelompok intervensi 352,84 \pm 48,54. Rerata frekuensi tonsilitis akut pada kelompok kontrol lebih tinggi dibandingkan dengan kelompok intervensi, yaitu sebesar 0,26 \pm 0,562 kali, sedangkan kelompok intervensi sebesar 0,21 0,419 kali. Tidak terdapat perbedaan pada frekuensi kejadian dan skor tanda gejala tonsilitis antara kelompok kontrol dan intervensi $(p>0,05)$

Simpulan : Rerata kejadian tonsilitis pada kelompok kontrol lebih tinggi dibandingkan kelompok intervensi, namun tidak terdapat perbedaan yang signifikan.
\end{abstract}

Kata kunci : ISPA, tonsilitis, suplementasi seng

\section{PENDAHULUAN}

Tonsilitis merupakan peradangan yang terjadi pada tonsil yang disebabkan oleh virus atau bakteri sehingga tonsil menjadi bengkak, merah, melunak, dan memiliki bintik-bintik putih di permukaannya. ${ }^{1}$ Tonsilitis merupakan salah satu infeksi saluran pernapasan bagian atas (ISPA) yang sering terjadi pada balita. Hal ini dikarenakan sistem imunologis pada tonsil manusia paling aktif pada usia antara 4 sampai dengan 10 tahun. $^{2,3}$ Tonsilitis dapat menyebabkan balita mengalami kesulitan menelan, serta apneu obstruksi saat tidur dengan hipoksia ringan sampai berat. ${ }^{4,5}$ Berdasarkan survei epidemiologi penyakit telinga, hidung, dan tenggorokan (THT) di 7 provinsi di Indonesia pada tahun 1994-1996, prevalensi tonsilitis kronis sebesar $3,8 \%$, tertinggi kedua setelah nasofaring akut $(4,6 \%){ }^{6}$ Kejadian tonsilitis kronis di Rumah Sakit Umum Pusat (RSUP) dr. Kariadi Semarang dilaporkan oleh Aritomoyo pada tahun 1978 sebanyak $23,36 \%$ dan $47 \%$ diantaranya pada usia 6 15 tahun. $^{4}$ 
Bayi dan anak-anak di bawah usia lima tahun atau balita merupakan kelompok yang rentan terhadap berbagai penyakit. ISPA menempati urutan pertama penyakit yang diderita oleh kelompok bayi dan balita di Indonesia. Menurut Riskesdas 2013, prevalensi ISPA selama tahun 2013 mencapai 25,0\% dengan total kasus sekitar 2,33 juta. Sedangkan di Provinsi Jawa Tengah sendiri masih tergolong tinggi yaitu sebanyak $15,7 \% .^{7}$ Hal ini menunjukkan bahwa sistem kekebalan tubuh pada balita belum terbentuk sempurna sehingga rentan terserang penyakit infeksi.

Asupan gizi yang terpenuhi dengan baik berkaitan dengan meningkatnya fungsi sistem kekebalan tubuh terhadap berbagai penyakit. Salah satu mineral yang berperan penting dalam sistem kekebalan tubuh yaitu seng. Seng merupakan mineral kedua yang jumlahnya berlimpah dalam tubuh. Seng memiliki tiga fungsi biologis penting dalam tubuh, yaitu fungsi katalisator, fungsi struktural, dan pengaturan. ${ }^{8}$ Seng juga berperan dalam stabilitas membran, memacu pertumbuhan, maturasi seksual, dan menjaga integritas sel, sistem imunitas spesifik maupun non-spesifik, aktivitas banyak enzim termasuk superoxide dismutase, carbonic anhidrase, dan matriks metalloproteinase, serta aktivitas antioksidan. Karena fungsinya dalam menjaga imunitas spesifik dan non spesifik, seng memiliki peran penting dalam pengendalian dan pencegahan penyakit infeksi pada manusia. ${ }^{8,9}$

Defisiensi seng dapat menyebabkan penurunan imunitas seluler tubuh. ${ }^{10}$ Defisiensi seng yang parah menekan fungsi imunitas tubuh dan bahkan defisiensi seng ringan sampai sedang dapat mengganggu fungsi makrofag dan neutrofil, $\mathrm{T}$ Helper-1 dan $\mathrm{T}$ Helper-2, aktivitas sel pembunuh alami (NK), serta aktivitas komplemen. ${ }^{11,12}$

Hasil survey di 12 provinsi di Indonesia menemukan prevalensi defisiensi seng pada anak balita rata-rata $36,1 \% .{ }^{13}$ Penelitian mengenai asupan seng pada balita juga pernah dilakukan di kelurahan Jomblang, Semarang. Hasil penelitian menunjukkan bahwa dari 65 responden, terdapat 26,2\% atau 17 responden yang kekurangan asupan seng. ${ }^{14} \mathrm{Hal}$ ini menunjukkan bahwa tingkat konsumsi seng di Indonesia pada balita masih kurang dari angka kecukupan gizi (AKG) yang dianjurkan.

Salah satu solusi untuk meningkatkan asupan seng adalah dengan suplementasi. Penelitian mengenai suplementasi seng pada penyakit infeksi pernapasan menunjukkan efek penurunan kejadian penyakit infeksi pernafasan, seperti pneumonia. Suatu meta analisis menemukan bahwa suplementasi seng berdampak terhadap pengurangan insidensi pneumonia, atau penyakit saluran pernafasan pada anak balita. ${ }^{15}$ Selain itu pada kasus diare, pemberian suplementasi seng oral dapat mempengaruhi jumlah anak yang menderita diare, frekuensi diare, dan durasi diare. ${ }^{16}$ Namun, penelitian mengenai pengaruh suplementasi seng terhadap tonsilitis belum dilakukan. Penelitian ini pemberian suplemen seng dengan dosis $10 \mathrm{mg} /$ hari dilakukan selama 2 bulan.

\section{METODE}

Penelitian ini dilakukan di Tandang Ijen, Kelurahan Jomblang, Kecamatan Candisari, Kota Semarang dan termasuk dalam penelitian lingkup bidang gizi masyarakat. Desain penelitian menggunakan metode Randomized Controlled Trial (RCT) dimana subjek ditempatkan secara random kedalam 2 kelompok yaitu kelompok intervensi dan kelompok kontrol. Penelitian ini merupakan penelitian true eksperimental dengan post test only control group design, dimana pemeriksaan subjek dilakukan pada akhir intervensi untuk melihat pengaruh intervensi. Intervensi yang diberikan adalah pemberian suplemen seng dengan dosis $10 \mathrm{mg} / \mathrm{hari}$. Penelitian ini dilakukan dengan dasar Ethical Clearance (EC) nomor 524/EC/FK-RSDK/VII/2018 yang dikeluarkan oleh Fakultas Kedokteran Universitas Diponegoro.

Subjek pada penelitian ini merupakan balita yang bertempat tinggal di Kelurahan Jomblang, Kecamatan Candisari, Kota Semarang dengan kriteria inklusi berusia 2 sampai dengan 5 tahun, dalam keadaan sehat, dan orang tua bersedia menjadi subjek penelitian dengan mengisi Informed Consent. Kriteria eksklusi yaitu subjek pindah domisili, dan tidak kooperatif selama masa penelitian.

Berdasarkan perhitungan, diperoleh besar sampel minimal sebanyak 16 . Untuk menghindari terjadinya drop out, subjek penelitian ditambahkan $20 \%$ sehingga diperoleh jumlah sampel masingmasing kelompok adalah 20. Penelitian ini terdapat 2 kelompok, sehingga total sampel adalah 40 yang terbagi menjadi 2 kelompok yaitu kelompok intervensi dan kelompok kontrol. Subjek yang memenuhi kriteria inklusi kemudian diikutsertakan dalam penelitian. Suplemen diberikan kepada ibu atau pengasuh untuk diberikan kepada subjek dengan frekuensi pemberian satu kali dalam sehari selama 2 bulan, dan kelompok kontrol diberikan sirup plasebo. Kelompok intervensi diberikan suplemen seng sebanyak $10 \mathrm{mg} / \mathrm{hari}$. Selanjutnya dilakukan pemeriksaan tonsilitis setiap minggunya. Saat penelitian dilaksanakan, terdapat subjek yang dropout dari kelompok kontrol dan intervensi masing-masing 1 subjek. Hal ini dikarenakan subjek pada kelompok kontrol pindah domisili ke luar Kota Semarang dan subjek pada kelompok intervensi menolak untuk diberikan suplemen ditengah masa penelitian. 
Variabel terikat dalam penelitian ini adalah kejadian tonsilitis pada balita, dan variabel bebasnya adalah pemberian suplemen seng. Kejadian tonsilitis didefinisikan sebagai jumlah kejadian tonsilitis baik akut maupun kronis dengan gejala batuk, demam, nyeri pada tenggorokan, kesulitan menelan, dan adanya pembengkakan pada tonsil. Tonsilitis akut adalah peradangan tonsil yang terjadi secara cepat (akut) dalam waktu kurang dari 2 minggu. Tonsilitis kronis adalah infeksi atau inflamasi pada tonsil yang menetap yang dapat mengakibatkan kerusakan permanen pada tonsil. ${ }^{17,18}$

Diagnosis tonsilitis dilakukan oleh dokter dengan menggunakan anamnesis dan pemeriksaan fisik. Setiap gejala yang ditemukan diberi skor masing-masing 1, sehingga apabila ditemukan lebih dari 1 gejala seperti batuk, demam $>38^{\circ} \mathrm{C}$, pembengkakan tonsil, nyeri tekan pada kelenjar getah bening di leher, dan kesulitan menelan, maka skor dijumlahkan sesuai dengan gejala yang ditemukan. Durasi tonsilitis juga diperhitungkan, apabila tonsilitis berlangsung kurang dari 2 minggu maka diberi skor 1 dan apabila berlangsung selama lebih dari 4 minggu atau menetap diberi skor 2. Total skor gejala merupakan penjumlahan dari banyaknya tanda atau gejala tersebut diatas yang terdapat pada subjek selama intervensi.

Variabel perancu pada penelitian ini adalah asupan seng, zat besi, protein, dan fitat yang didapat dari sumber makanan. Data asupan makanan merupakan jumlah asupan yang diasup oleh subjek yang diperoleh dari wawancara Semi Quantitative Food Frequency Questionnaire (SQFFQ) kepada ibu atau pengasuh. Hasil SQFFQ selanjutnya dianalisis dengan Nutrisurvey 2004 dan dibandingan dengan AKG untuk mengetahui persentase asupan seng, zat besi, protein, dan fitat yang dikonsumsi subjek. Tingkat kecukupan seng dan zat besi dikelompokkan menjadi kurang yaitu apabila konsumsi $<77 \%$ dari AKG, dan cukup apabila konsumsi $\geq 77 \%$ AKG. ${ }^{19}$ Sedangkan tingkat kecukupan protein tergolong kurang apabila konsumsi $<80 \%$ angka kecukupan gizi (AKG) dan tergolong cukup apabila konsumsi mencapai $\geq 80 \%$ AKG. $^{20}$ Asam fitat merupakan inhibitor yang kuat dalam absorbsi mineral dalam tubuh. Absorbsi mineral yang dapat terganggu akibat tingginya konsumsi fitat diantaranya seperti zat besi, seng, kalsium, dan mangan. ${ }^{21}$ Tingkat konsumsi fitat yang dapat menghambat absorbsi mineral tersebut dihitung menggunakan rasio fitat:mineral. Pada penelitian ini, tingkat konsumsi fitat dihitung menggunakan rasio molar fitat:seng, dimana rasio molar fitat: seng yang bioavailabilitasnya tergolong baik yaitu pada indikator $<15$ dan akan menurun ketika rasio molar fitat:sengnya mencapai $>15$. Hal ini berarti tingkat absorbsi seng dapat dikategorikan tinggi apabila rasio molar fitat:seng $<15$ dan rendah apabila rasio molar fitat:seng $>15 .^{22,23}$

Rasio molar fitat : seng pada makanan dapat dikalkulasikan sebagai berikut :

Keterangan :

$$
\frac{m g \text { fitat } / 660}{m g \text { seng } / 65,4}
$$

- $660=$ massa molekul fitat

- $\quad 65,4=$ massa molekuler seng

Data yang diperoleh dianalisis statistik menggunakan program komputer. Uji normalitas data dilakukan dengan uji Saphiro-Wilk karena jumlah sampel yang digunakan $<50$. Perbedaan persentase asupan selama intervensi pada masing-masing kelompok dianalisis menggunakan uji Independent $T$ test karena data berdistribusi normal. Sedangkan perbedaan frekuensi kejadian tonsilitis dan skor tanda gejala tonsilitis antar kelompok dianalisis menggunakan uji Mann Whitney U Test dikarenakan data berdistribusi tidak normal.

\section{HASIL \\ Karakteristik Subjek}

Karakteristik subjek terdiri dari jenis kelamin, usia, status gizi, dan tingkat kecukupan asupan seng, besi, protein, dan rasio molar fitat:seng pada saat sebelum intervensi yang disajikan dalam tabel 1. Penelitian ini melibatkan 38 subjek balita berusia 2-5 tahun yang terbagi menjadi kelompok suplementasi seng dan kelompok kontrol.

Tabel 1 menunjukkan karakteristik subjek berupa jenis kelamin, usia, status gizi berdasarkan $\mathrm{BB} / \mathrm{U}$ dan $\mathrm{TB} / \mathrm{U}$, serta tingkat kecukupan gizi subjek sebelum intervensi. Sebagian besar subjek pada kedua kelompok berjenis kelamin perempuan, yaitu sebesar $68,4 \%(\mathrm{n}=13)$ pada kelompok kontrol, dan 52,6\% $(n=10)$ pada kelompok intervensi. Sebagian besar subjek pada kedua kelompok berusia 24-36 bulan pada saat penelitian dilakukan, yaitu sebanyak 57,9\% $(n=11)$ pada kelompok kontrol dan juga 57,9\% $(\mathrm{n}=11)$ pada kelompok intervensi. Status gizi subjek berdasarkan $\mathrm{Z}$ skor BB/U menunjukkan 94,7\% $(\mathrm{n}=18)$ subjek pada kelompok kontrol dan $78,9 \%$ $(\mathrm{n}=15)$ subjek pada kelompok intervensi memiliki status gizi baik dan berdasarkan skor TB/U menunjukkan 84,2\% ( $\mathrm{n}=16)$ subjek pada kelompok kontrol dan 52,6\% (n=10) subjek pada kelompok intervensi berstatus gizi normal.

Berdasarkan tingkat kecukupan asupan subjek pada saat sebelum intervensi pada tabel 1, sebanyak $89,5 \%$ $(\mathrm{n}=17)$ subjek pada kelompok kontrol dan $89,5 \%$ $(n=17)$ subjek pada kelompok intervensi memiliki tingkat kecukupan seng yang tergolong cukup. Untuk tingkat kecukupan besi, sebanyak 78,9\% $(\mathrm{n}=15)$ subjek pada kelompok kontrol dan 73,7\% ( $\mathrm{n}=14)$ subjek pada kelompok intervensi tergolong cukup, 
sedangkan untuk tingkat kecukupan protein pada kelompok kontrol 73,7\% ( $\mathrm{n}=14)$ subjek tergolong cukup dan $68,4 \%(\mathrm{n}=13)$ subjek pada kelompok intervensi tergolong cukup. Rasio molar fitat: seng pada kedua kelompok sebagian besar juga menunjukkan tingkat absorbsi seng yang tinggi. Pada kelompok kontrol sebanyak 73,7\% (n=14) subjek memiliki tingkat absorbsi seng yang tinggi, sedangkan pada kelompok intervensi sebanyak $94,7 \%(n=18)$ subjek memiliki tingkat absorbsi seng yang tinggi.

Tabel 1. Distribusi Jenis Kelamin, Usia, Status Gizi, dan Tingkat Kecukupan Gizi

\begin{tabular}{|c|c|c|c|c|}
\hline \multirow[t]{2}{*}{ Karakteristik Subjek } & \multicolumn{2}{|c|}{ Kelompok Kontrol } & \multicolumn{2}{|c|}{$\begin{array}{l}\text { Kelompok } \\
\text { Intervensi }\end{array}$} \\
\hline & $\mathbf{n}$ & $\%$ & $\mathbf{n}$ & $\%$ \\
\hline \multicolumn{5}{|l|}{ Jenis Kelamin } \\
\hline Laki-laki & 6 & 31,6 & 9 & 47,4 \\
\hline Perempuan & 13 & 68,4 & 10 & 52,6 \\
\hline \multicolumn{5}{|l|}{ Usia } \\
\hline 24-36 bulan & 11 & 57,9 & 11 & 57,9 \\
\hline $37-48$ bulan & 7 & 36,8 & 3 & 15,8 \\
\hline $49-60$ bulan & 1 & 5,3 & 5 & 26,3 \\
\hline \multicolumn{5}{|l|}{ Status Gizi $\mathbf{B B} / \mathbf{U}$} \\
\hline Gizi Buruk & 0 & 0 & 0 & 0 \\
\hline Gizi Kurang & 1 & 5,3 & 4 & 21,1 \\
\hline Gizi Baik & 18 & 94,7 & 15 & 78,9 \\
\hline Gizi Lebih & 0 & 0 & 0 & 0 \\
\hline \multicolumn{5}{|l|}{ Status Gizi TB/U } \\
\hline Tinggi & 0 & 0 & 0 & 0 \\
\hline Normal & 16 & 84,2 & 10 & 52,6 \\
\hline Pendek & 3 & 15,8 & 8 & 42,1 \\
\hline Sangat pendek & 0 & 0 & 1 & 5,3 \\
\hline \multicolumn{5}{|l|}{ Asupan Seng } \\
\hline Kurang & 2 & 10,5 & 2 & 10,5 \\
\hline Cukup & 17 & 89,5 & 17 & 89,5 \\
\hline \multicolumn{5}{|l|}{ Asupan Besi } \\
\hline Kurang & 4 & 21,1 & 5 & 26,3 \\
\hline Cukup & 15 & 78,9 & 14 & 73,7 \\
\hline \multicolumn{5}{|l|}{ Asupan Protein } \\
\hline Kurang & 5 & 26,3 & 6 & 31,6 \\
\hline Cukup & 14 & 73,7 & 13 & 68,4 \\
\hline \multicolumn{5}{|l|}{ Rasio Molar Fitat:seng } \\
\hline Tinggi & 14 & 73,7 & 18 & 94,7 \\
\hline Rendah & 5 & 26,3 & 1 & 5,3 \\
\hline
\end{tabular}

Tabel 2. Rerata Persentase Kecukupan Zat Gizi Sebelum Intervensi

\begin{tabular}{lccc}
\hline \multirow{2}{*}{ Karakteristik Subjek } & Kelompok Kontrol & Kelompok Intervensi & \multirow{2}{*}{ p } \\
\cline { 2 - 3 } & Mean \pm SD & Mean \pm SD & \\
\hline Kecukupan Asupan (\%) & $151,11 \pm 56,15$ & $130,39 \pm 50,35$ & $0,239^{\mathrm{a}}$ \\
Seng & $142,29 \pm 67,92$ & $108,22 \pm 45,78$ & $0,136^{\mathrm{b}}$ \\
Besi & $116,85 \pm 44,02$ & $99,56 \pm 35,41$ & $0,157^{\mathrm{b}}$ \\
Protein & $11,23 \pm 5,63$ & $9,66 \pm 3,30$ & $0,303^{\mathrm{a}}$ \\
Rasio Molar Fitat:seng & &
\end{tabular}

${ }^{\mathrm{a} U j \mathrm{ji} \text { Independent } T \text { Test; }{ }^{\text {' } U j i ~ M a n n ~ W h i t n e y ~ U ~ T e s t ~}}$

Tabel 2 menunjukkan rerata persentase kecukupan asupan seng, besi, protein, dan rasio molar fitat:seng sebelum intervensi pada kelompok kontrol dan intervensi. Berdasarkan tabel tersebut tidak terdapat perbedaan yang signifikan rerata persentase kecukupan gizi sebelum intervensi antara kelompok kontrol dan intervensi, sehingga dapat dikatakan asupan kedua kelompok pada saat sebelum intervensi hampir sama. 
Tabel 3. Rerata Persentase Kecukupan Zat Gizi Selama Intervensi Tanpa Suplementasi

\begin{tabular}{lccc}
\hline \multirow{2}{*}{ Karakteristik Subjek } & Kelompok Kontrol & Kelompok Intervensi & \multirow{2}{*}{ p } \\
\cline { 2 - 3 } Kecukupan Asupan (\%) & Mean \pm SD & Mean \pm SD & \\
Seng & $137,42 \pm 50,05$ & $121,26 \pm 37,17$ & $0,266^{\mathrm{a}}$ \\
Besi & $109,06 \pm 30,22$ & $93,20 \pm 26,11$ & $0,092^{\mathrm{a}}$ \\
Protein & $101,77 \pm 28,11$ & $90,25 \pm 24,39$ & $0,186^{\mathrm{a}}$ \\
Rasio Molar Fitat:seng & $10,90 \pm 6,20$ & $10,39 \pm 4,42$ & $0,771^{\mathrm{a}}$ \\
\hline
\end{tabular}

${ }^{\mathrm{a} U j i}$ Independent T Test

Tabel 3 menunjukkan perbedaan rerata persentase kecukupan seng, besi, protein, dan rasio molar fitat:seng antara kelompok kontrol dan intervensi tanpa suplementasi. Berdasarkan tabel tersebut, tidak terdapat perbedaan yang signifikan pada nilai rerata kecukupan seng, besi, protein, dan rasio molar fitat:seng antara kedua kelompok. Hal ini berarti bahwa kedua kelompok tersebut memiliki rerata persentase kecukupan asupan yang sama selama penelitian.

Tabel 4. Rerata Persentase Kecukupan Zat Gizi Selama Intervensi Dengan Suplementasi

\begin{tabular}{lccc}
\hline \multirow{2}{*}{ Karakteristik Subjek } & Kelompok Kontrol & Kelompok Intervensi & \multirow{2}{*}{$\mathbf{p}$} \\
\cline { 2 - 3 } Kecukupan Asupan (\%) & Mean \pm SD & Mean \pm SD & $0,000^{\mathrm{a}}$ \\
Seng & $137,42 \pm 50,05$ & $352,84 \pm 48,54$ & $0,092^{\mathrm{a}}$ \\
Besi & $109,06 \pm 30,22$ & $93,20 \pm 26,11$ & $0,186^{\mathrm{a}}$ \\
Protein & $101,77 \pm 28,11$ & $90,25 \pm 24,39$ & $0,000^{\mathrm{b}}$ \\
Rasio Molar Fitat:seng & $10,90 \pm 6,20$ & $3,29 \pm 1,11$ & \\
\hline
\end{tabular}

${ }^{\mathrm{a} U j i}$ Independent T Test; ${ }^{\mathrm{b}} \mathrm{Uji}$ Mann Whitney U Test

Tabel 4 menunjukkan perbedaan rerata persentase kecukupan seng, besi, protein, dan rasio molar fitat : seng pada kedua kelompok dengan suplementasi. Berdasarkan tabel tersebut dapat disimpulkan bahwa terdapat perbedaan yang signifikan pada nilai rerata tingkat kecukupan seng dan rasio molar fitat:seng antara kelompok kontrol dan intervensi.

Tabel 5. Frekuensi dan Skor Tanda Gejala Tonsilitis

\begin{tabular}{lccc}
\hline & $\begin{array}{c}\text { Kelompok } \\
\text { Kontrol }(\mathbf{n}=\mathbf{1 9})\end{array}$ & $\begin{array}{c}\text { Kelompok } \\
\text { Intervensi (n=19) }\end{array}$ & \multirow{2}{*}{ p } \\
\cline { 2 - 3 } & Mean \pm SD & Mean \pm SD & \\
\hline Frekuensi Tonsilitis akut & $0,26 \pm 0,562$ & $0,21 \pm 0,419$ & $0,934^{\mathrm{b}}$ \\
Skor Gejala Tonsilitis & $1,26 \pm 2,579$ & $1,00 \pm 1,795$ & $0,986^{\mathrm{b}}$ \\
\hline
\end{tabular}

${ }^{\mathrm{b} U j i}$ Mann Whitney U Test

Tabel 5 menunjukkan rerata frekuensi tonsilitis akut pada kelompok kontrol dan intervensi selama penelitian dilaksanakan. Rerata frekuensi tonsilitis akut pada kelompok kontrol lebih tinggi dibandingkan dengan kelompok intervensi, yaitu sebesar 0,26 $\pm 0,562$ kali, sedangkan kelompok intervensi sebesar 0,21 $\pm 0,419$ kali. Hasil uji statistik menunjukkan bahwa tidak terdapat perbedaan yang signifikan pada frekuensi tonsilitis akut antara kelompok kontrol dan kelompok intervensi $(p>0,05)$.

Berdasarkan skor tanda gejala tonsilitis, kelompok kontrol memiliki skor yang lebih tinggi yaitu $1,26 \pm 2,579$. Hal ini berarti kelompok kontrol memiliki tanda gejala tonsilitis yang lebih banyak dibandingkan dengan kelompok intervensi yang memiliki skor $1,00 \pm 1,795$. Hasil uji statistik juga menunjukkan tidak terdapat perbedaan yang signifikan tanda gejala tonsilitis antara kelompok kontrol dan intervensi ( $p>0,05)$.

\section{PEMBAHASAN}

Saat penelitian dilakukan, sebagian besar subjek pada kelompok kontrol maupun intervensi berjenis kelamin perempuan dan berusia 24-36 bulan. Usia dibawah lima tahun merupakan masa yang retan terhadap berbagai penyakit dan masalah gizi. Hal ini terjadi karena sistem kekebalan tubuh balita yang belum terbentuk sempurna. ${ }^{24}$ Tonsilitis merupakan salah satu infeksi pada saluran pernapasan bagian atas (ISPA) yang sering terjadi pada balita. Hal ini dikarenakan sistem imunologis pada tonsil di masa ini sering mengalami penurunan sehingga memudahkan virus dan bakteri masuk dan menimbulkan infeksi pada tonsil. ${ }^{2,3}$ Usia balita juga merupakan masa anakanak bermain bersama dan tanpa sengaja melakukan 
kontak langsung dengan teman atau lingkungan yang mungkin terpapar virus dan bakteri penyebab tonsilitis. $^{25}$

Status gizi sebagian besar subjek pada kelompok kontrol maupun intervensi termasuk dalam kategori status gizi baik berdasarkan $\mathrm{Z}$ skor BB/U dan normal berdasarkan Z skor TB/U. Tingkat kecukupan asupan seng, zat besi, protein, dan rasio molar fitat:seng pada kelompok kontrol dan intervensi pada saat sebelum intervensi juga dikaji untuk melihat tingkat kecukupan asupan subjek. Tingkat kecukupan asupan seng, zat besi, dan protein sebagian besar subjek pada kedua kelompok pada saat sebelum intervensi tergolong cukup yaitu $\geq 77 \%$ untuk seng dan zat besi, dan $\geq 80 \%$ untuk protein. Rasio molar fitat: seng pada kedua kelompok pada saat sebelum intervensi juga menunjukkan tingkat absorbsi seng yang tinggi (Phy:Zn <15). Berdasarkan status gizi dan data kecukupan gizi sebelum intervensi dapat disimpulkan bahwa sebagian besar subjek pada kedua kelompok memiliki kararteristik yang sama.

Status gizi dapat menggambarkan baik atau buruknya pemenuhan kebutuhan gizi pada balita. Status gizi yang kurang dapat menyebabkan berkurangnya daya tahan tubuh terhadap penyakit. Zat gizi tertentu yang berperan dalam fungsi kekebalan tubuh dikenal sebagai imunonutrisi. Imunonutrisi merupakan kumpulan zat gizi spesifik seperti protein, asam lemak omega-3, vitamin, dan mineral termasuk seng, yang memiliki pengaruh terhadap sistem kekebalan tubuh dan inflamasi yang telah terbukti klinis dan laboratorik. ${ }^{26}$ Defisiensi zat gizi tersebut dapat menyebabkan terjadinya infeksi dan mempengaruhi sistem kekebalan tubuh diantaranya menurunkan hipersensitivitas, mengurangi konsentrasi immunoglobulin, limfosit, produksi immunoglobulin A dan sel T. Namun apabila kebutuhan gizi dapat terpenuhi dengan baik, akan berdampak pula pada sistem kekebalan tubuh yang akan terjaga dengan baik sehingga balita tidak mudah terserang penyakit. ${ }^{24}$

Hasil penelitian ini menunjukkan tidak ada perbedaan yang signifikan pada frekuensi kejadian tonsilitis dan skor tanda gejala tonsilitis antara kelompok kontrol dan intervensi. Belum banyak penelitian yang menghubungkan pengaruh suplementasi seng terhadap tonsilitis. Namun sudah ada beberapa penelitian sebelumnya yang membahas mengenai efek suplementasi seng terhadap ISPA. Seperti penelitian yang dilakukan oleh Kartasurya yang menunjukkan bahwa tidak ada perbedaan yang signifikan kejadian infeksi pada saluran pernafasan bagian atas antara kelompok yang diberikan intervensi seng $10 \mathrm{mg} /$ hari dalam waktu 4 bulan dan kelompok kontrol. ${ }^{27}$ Penelitian yang dilakukan oleh
Nair pada balita usia 2-60 bulan juga menunjukkan tidak ada perbedaan yang signifikan pada penurunan durasi dan frekuensi kejadian infeksi saluran pernafasan di bagian atas antara kelompok placebo dan kelompok yang diberikan suplementasi seng 10 dan 20mg selama 14 hari. ${ }^{28}$ Penelitian yang dilakukan oleh Malik pada bayi 6-12 bulan menunjukkan tidak ada perbedaan yang signifikan pada penurunan frekuensi kejadian ISPA antara kelompok placebo dan kelompok yang diberi intervensi seng $20 \mathrm{mg}$ selama 14 hari, namun terdapat penurunan lama waktu kesakitan selama periode follow up. ${ }^{29}$

Berdasarkan tabel 3 menunjukkan rerata frekuensi kejadian tonsilitis pada kelompok kontrol $0,26 \pm 0,562$ dan kelompok intervensi 0,21 $\pm 0,419$ yang berarti terdapat kecenderungan lebih rendah pada kelompok intervensi, namun belum signifikan secara statistik. Hasil skor tanda dan gejala tonsillitis juga menunjukkan kecenderungan lebih tinggi pada kelompok kontrol yaitu sebesar 1,26 $\pm 2,579$ dibandingkan dengan kelompok intervensi sebesar $1,00 \pm 1,795$, meskipun secara statistik tidak terdapat perbedaan yang signifikan. Hal ini dapat dipengaruhi oleh beberapa faktor seperti dosis dan durasi suplementasi yang belum maksimal sehingga belum dapat menggambarkan adanya perbedaan frekuensi kejadian tonsilitis yang signifikan antara kedua kelompok. Belum banyak penelitian yang membahas mengenai pengaruh suplementasi seng terhadap tanda dan gejala tonsilitis. Namun tanda dan gejala yang sering muncul adalah timbulnya demam, batuk, nyeri tenggorok, nyeri dan kesulitan saat menelan, serta pembengkakan pada tonsil. ${ }^{30}$ Gejala tersebut merupakan manifestasi klinis akibat terjadinya infeksi pada tonsil.

Seng merupakan salah satu imunonutrisi yang berperan penting dalam sistem imunitas spesifik maupun non spesifik guna melawan infeksi. Pada sistem imunitas spesifik seng memegang peranan penting terhadap fungsi timus. Seng berperan sebagai kofaktor esensial terhadap hormon timulin (ZnFTS) yang dihasilkan timus melalui sel epitel timus. Seng tidak hanya berperan pada proses diferensiasi sel $\mathrm{T}$ yang belum matang, namun juga mengatur pelepasan sitokin, merangsang pembentukan sel $\mathrm{T}$ CD8, bersama dengan interleukin 2 (IL-2), serta menjaga aktivitas reseptor untuk IL-2 pada sel T yang matang. Seng juga diperlukan dalam proses mitogenesis sel limfosit B. Pada sistem imunitas non spesifik, seng berperan dalam menjaga stabilitas membran dan kekebalan barrier kulit. Seng juga dibutuhkan untuk menjaga fungsi normal sel NK. Defisiensi seng dapat menyebabkan terganggunya kemampuan fagositosis dari makrofag dan neutrofil, penurunan killing activity dan fungsi NK, tahap reaksi oksidatif, dan komplemen. ${ }^{31}$ 
Perbedaan frekuensi tonsilitis dan skor tanda gejala tonsilitis yang tidak signifikan juga dapat disebabkan oleh tingkat kecukupan asupan subjek. Hasil penelitian menunjukkan bahwa tingkat kecukupan seng subjek pada kedua kelompok pada saat sebelum dan selama intervensi sebagian besar tergolong cukup, sehingga kebutuhan seng dalam tubuh subjek sudah dapat terpenuhi dari asupan makanan diluar suplemen.

Selama masa intervensi seng $10 \mathrm{mg} / \mathrm{hari}$, rerata tingkat kecukupan seng pada kelompok intervensi yang sudah tergolong cukup, mengalami peningkatan menjadi 352,84\% (rerata asupan 15,26 $\mathrm{mg} / \mathrm{hari}$ ). Asupan seng tersebut berada di bawah batas tolerable upper intake (UL). Tolerable Upper Intake (UL) merupakan tingkat rata-rata tertinggi asupan harian sebagai batas agar tidak menimbulkan risiko efek kesehatan yang merugikan populasi umum. UL seng merurut WHO yaitu $23 \mathrm{mg} / \mathrm{hari} .{ }^{32} \mathrm{Hal}$ ini berarti tingkat asupan subjek pada kelompok intervensi selama penelitian masih tergolong aman dan dapat ditoleransi. Asupan seng yang berlebihan dapat menyebabkan toksisitas dengan manifestasi klinis berupa sakit kepala, mual, muntah, dan diare. ${ }^{32}$

Tingkat kecukupan asupan besi subjek pada saat sebelum dan selama intervensi sebagian besar tergolong cukup dan tidak terdapat perbedaan yang signifikan kecukupan besi antara kedua kelompok saat sebelum dan selama intervensi. Tingkat kecukupan protein subjek saat sebelum intervensi sebagian besar juga tergolong cukup dan tidak terdapat perbedaan yang signifikan rerata kecukupan protein antar kedua kelompok baik sebelum dan selama intervensi. Hal ini menunjukkan bahwa asupan protein subjek hampir sama dan kebutuhan protein subjek terpenuhi dengan baik. Asupan protein merupakan aspek yang penting terhadap absorbsi seng. Jumlah protein pada makanan berkorelasi positif terhadap absorbsi seng. Protein berfungsi sebagai transporter yang mengangkut seng dan sebagai ligan untuk membantu meningkatkan absorbsi seng, sehingga apabila asupan protein tubuh terpenuhi dengan baik maka absorbsi seng pun meningkat. ${ }^{33}$

Selain itu, tabel 2 dan 3 menunjukkan rasio molar fitat:seng pada kedua kelompok pada saat sebelum dan selama pelaksanaan intervensi menunjukkan rerata $<15$, sehingga dapat dikatakan tingkat absorbsi seng cukup tinggi dalam tubuh. Fitat merupakan senyawa yang dapat mengikat unsurunsur mineral seperti seng sehingga menjadi sulit untuk dicerna dan mengakibatkan ketersediaan seng dalam tubuh menurun. Asam fitat juga dapat bereaksi dengan protein membentuk senyawa kompleks sehingga dapat menghambat pencernaan protein oleh enzim proteolitik dan kompleks protein fitat tersebut berkemampuan mengikat mineral yang lebih besar dibandingkan dengan asam fitat bebas. ${ }^{33}$ Efek penghambatan fitat dalam absorbsi seng dapat dihitung menggunakan rasio molar fitat : seng yang apabila rasionya $>15$ maka dapat dikatakan fitat lebih dominan sehingga absorbsi seng menjadi rendah atau terganggu, namun apabila rasionya $<15$ maka dapat dikatakan baik karena tidak mempengaruhi absorbsi seng sehingga absorbsi seng cukup tinggi dalam tubuh. ${ }^{22}$

\section{SIMPULAN}

Kelompok kontrol menunjukkan rerata kejadian tonsilitis yang lebih tinggi dibandingkan kelompok intervensi yang diberikan suplementasi seng, meskipun hasil uji statistik menunjukkan tidak ada perbedaan yang signifikan.

\section{SARAN}

Sebaiknya suplementasi seng dengan dosis yang sesuai usia dengan memperhatikan UL seng untuk balita yaitu $23 \mathrm{mg}$, untuk meningkatkan kekebalan tubuh balita dari infeksi, dipertimbangkan sebagai program kesehatan yang dilakukan secara rutin dan merata, terutama pada subjek yang mengalami defisiensi, sehingga dapat menurunkan angka kejadian tonsilitis pada balita. Selain itu untuk para pengasuh subjek diharapkan dapat selalu menjaga dan memperhatikan kecukupan asupan seng dan zat gizi lain pada balita untuk mencegah terjadinya tonsilitis.

\section{UCAPAN TERIMA KASIH}

Peneliti mengucapkan terima kasih kepada dr. Martha Ardiaria,M.Si.Med., dr.Aryu Candra, M.Kes.Epid., dan Ibu Dewi Marfu'ah Kurniawati, S.Gz., M.Gizi selaku penguji dan pembimbing, atas bimbingan, saran, dan masukan yang membangun untuk karya tulis ilmiah ini. Terima kasih kepada orangtua, keluarga, sahabat, dan teman-teman yang telah mendoakan, seluruh subjek yang berpartisipasi pada penelitian ini yaitu warga kelurahan Jomblang yang telah memberikan kesempatan untuk melakukan penelitian, dan semua pihak yang telah memotivasi dan mendukung sehingga penelitian ini terselesaikan.

\section{DAFTAR PUSTAKA}

1. Anand B. Karakteristik Penderita Tonsilitis Kronis di RSUP Haji Adam Malik Medan tahun 2014. Repositori Institusi Universitas Sumatera Utara tahun 2014. Available from: http://repository.usu.ac.id/handle/123456789/56 151

2. Campisi P, Tewfik TL. Tonsillitis and Its Complications. Canadian Journal of Diagnosis. 
2003;(February):99-105.

3. Panga A, Rani GU, Kumar MV. Chronic Tonsillitis: A Comparative Study of the Causative Organism Cultured Through Throat Swab vs . Core Culture and Biopsy of the Tonsillectomy Specimen. International Journal of Science and Research. 2016;5(4):1390-5.

4. Farokah. Hubungan Tonsilitis Kronik dengan Prestasi Belajar pada Siswa Sekolah Dasar di Kota Semarang. Repositori Institusi Universitas Diponegoro tahun 2005. Available from: http://eprints.undip.ac.id/12393/

5. Nizar $M$, Qamariah $N$, Muthmainah $N$. Identifikasi Bakteri Penyebab Tonsilitis Kronik pada Pasien Anak di Bagian THT RSUD Ulin Banjarmasin. Berkala Kedokteran Universitas Lambung Mangkurat Banjarmasin. 2016;12:197-204.

6. Theno GG, Tamus AY, Tumbel REC. Survei Kesehatan Tenggorokan Siswa SD Inpres 10/73 Pandu. Journal e-Clinic. 2016;4:2-5.

7. Wahyuningsih S, Raodhah S, Basri S. Infeksi Saluran Pernafasan Akut (ISPA) pada Balita di Wilayah Pesisir Desa Kore Kecamatan Sanggar Kabupaten Bima. Higiene. 2017;3.

8. Somuk BT, Sapmaz E, Soyalıç H, Yamanoglu M, Mendil D, Arici A, et al. Evaluation of Iron and Zinc Levels in Recurrent Tonsillitis and Tonsillar Hypertrophy. American Journal of Otolaryngol. 2015;7:7-10.

9. Cuevas LE, Koyanagi A. Zinc and Infection: A Review. Annals of Tropical Paediatrics Journal. 2005;25(June):149-60.

10. Yousefichaijan P, Naziri M, Taherahmadi H, Kahbazi M, Tabaei A. Zinc Supplementation in Treatment of Children with Urinary Tract Infection. Iranian Journal Kidney Disease. 2016;10(4):213-6.

11. Chasapis CT, Stefanidou M, Spiliopoulou C, Loutsidou AC. Zinc in Human Health: An Update. American Journal of Otolaryngol. 2011;86(4):521-34.

12. Rink L; Gabriel P. Zinc and the Immune System. Proceedings of Nutrition Society. 2000;59(4)

13. Herman S. Review On The Problem of Zinc Defficiency , Program Prevention and Its Prospect. Media Litbang Kesehatan. 2009; 19:75-83

14. Candra A, Ratna E, Ardiaria M, Probosari E. Pengaruh Suplementasi Seng dan Zat Besi terhadap Nafsu Makan, Status Gizi, dan Kecerdasan Intelektual (Intelligence Quotient) Balita. Universitas Diponegoro; 2016.

15. Das M, Das R. Need of Education and Awareness Towards Zinc Supplementation: A review. International Journal Nutrition and
Metabolism. 2012;4(March):45-50

16. Lazzerini M. Micronutrients for the Prevention and Treatment of Diarrhea in Children in Lowand Middle-Income Countries. Current Tropical Medicine Reports. 2014;106-10.

17. Stelter K. Tonsillitis and Sore Throat in Children. GMS Current Topics Otorhinolaryngology Head Neck Surgery. 2014;13:1-24.

18. Shalihat AO, Novialdi, Irawati L. Hubungan Jenis Kelamin dan Perlakuan Penatalaksanaan dengan Ukuran Tonsil pada Penderita Tonsilitis Kronis di Bagian THT-KL RSUP DR . M . Djamil. Jurnal Kesehatan Andalas. 2013;4(3):786-94.

19. Gibson R. Principles of Nutritional Assessment. New York: Oxford University; 2005.

20. Widyakarya Nasional Pangan dan Gizi (WNPG). Jakarta: Lembaga Ilmu Pengetahuan Indonesia; 2004.

21. Hurrell RF. Nutrient Composition for Fortified Complementary Foods Influence of Vegetable Protein Sources on Trace Element and Mineral Bioavailability. Nutrition Composition for Fortified Complementary Foods. 2003;(March):2973-7.

22. Lazarte CE, Carlsson NG, Almgren A, Sandberg AS, Granfeldt Y. Phytate, zinc, iron and calcium content of common Bolivian food, and implications for mineral bioavailability. Journal of Food Composition Analysis. 2015;39:111-9.

23. Hambridge KM, Miller L V, Wescott JE, Krebs NF. Dietary Reference Intakes for Zinc May Require Adjustment for Phytate Intake Based Upon Model Predictions. British Journal of Nutrition. 2014;66(4):29-49.

24. Sulistyoningsih H. Gizi Untuk Kesehatan Ibu dan Anak. Yogyakarta: Graha Ilmu; 2011.

25. Suyami S. Karakteristik Faktor Resiko ISPA pada Anak Usia Balita di Puskesmas Pembantu Krakitan, Bayat, Klaten. Ilmu Kesehatan. 2004

26. Angraini DI, Ayu PR. The Relationship Between Nutritional Status and Immunonutrition Intake with Immunity Status. Jurnal Kedokteran. 2014;4(8):158-65

27. Kartasurya MI, Ahmed F, Subagio HW, Rahfiludin MZ, Marks GC. Zinc Combined with Vitamin A Reduces Upper Respiratory Tract Infection Morbidity in A Randomised Trial in Preschool Children in Indonesia. British Journal of Nutrition. 2012;108(12):2251-60.

28. Nair BT, Bhunia R, Sharma KK. Role of Zinc Supplementation in Acute Respiratory Tract Infections in Children Aged 2 to 60 Months. International Journal of Contemporary Pediatrics. 2017;4(5):1758-62. 
29. Lamberti LM, Fischer-Walker CL, Black RE, Patel A, Shah I, Madvariya M. Prophylactic Zinc Supplementation for Prevention of Acute Respiratory Infections in Infants and Young Children. Indian Pediatrics. 2014;51(10):775-6.

30. Novialdi N, Pulungan MR. Mikrobiologi Tonsilitis Kronis. Repositori Institusi Universitas Andalas tahun $2010: 1-10$.

31. Rita NY, Evalina R, Irsa L. Peran Zink terhadap
Sistem Imun Anak. Majalah Kedokteran Nusantara. 2013;46(2):93-6.

32. Zlotkin S. A Critical Assessment of The Upper Intake Levels for Infants and Children. Journal of Nutrition. 2006;136(2):502S-506S.

33. Lonnerdal B. Zinc and Health : Current Status and Future Directions Dietary Factors Influencing Zinc Absorption. American Society for Nutrition Sciences. 2000;(March):1378-83 